\title{
The Possible Local Synthesis of Antibodies to Herpes Simplex Virus in Normal Cerebrospinal Fluid
}

\author{
ANTHONY SCIENCE RUSSELL
}

SUMMARY: We have used the technique of antibody mediated cell dependent immune lysis to examine paired samples of serum and CSF for antibody to herpes simplex virus. The 40 patients studied had no inflammatory disease of the nervous system, yet 20 of the CSF specimens did have antiviral antibody. This is an extremely sensitive technique for the detection of at least one type of antiviral antibody and "in vitro" is a

RESUMÉ: Nous avons utilisé la technique de lyse immune cellulo-dépendante par anti-corps pour examiner des échantillons pairés de sérum et de LCR à la recherche d'anti-corps au virus d'herpès simplex. Les 40 patients étudiés n'avaient pas de maladie inflammatoire du système nerveux, mais 20 des spécimens de LCR avaient des anti-corps contre le virus. II s'agit d'une technique extrêmement sensible pour la détection d'au moins un type d'anti-corps contre le very effective way of killing virus infected cells. There is no correlation between the level of antiviral antibody in the CSF with the total protein content, but the high CSF: serum antibody ratio in some subjects who are particularly susceptible to recurrent herpes infection raises the possibility that local stimulation and production of this antibody may occur.

virus et, "in vitro", c'est une méthode très efficace pour tuer les cellules infectées. Il n'y a pas de corrélation entre le niveau d'anti-corps antiviraux dans le LCR et le contenu total de proteines, mais le rapport LCR: anticorps sérique élevé chez certains sujets qui sont particulièrement susceptibles à l'infection récurrente d'herpès suggère la possibilité que la stimulation locale et la production de cet anti-corps puissent exister.

\section{INTRODUCTION}

Several studies have suggested that finding antibodies to herpes simplex virus (HSV) in cerebrospinal fluid (CSF) is indicative of active herpetic encephalitis (Lerner et al., 1972; Cappel et al., 1975). We have developed a very sensitive assay for antibodies to HSVI and have shown these antibodies to be frequently present in normal cerebrospinal fluid (Russell and Saetre, 1976).

The assay depends upon the ability of a minute amount of specific antibody to sensitise HSV infected target cells for lysis by unsensitized control mononuclear cells, ie. antibody dependent, cell mediated lysis (ADC) (Russell et al., 1975). In this study we have increased the number of our initial observations and demonstrated the sensitivity of this technique in the detection of antiviral antibodies.

\section{MATERIALS AND METHODS}

The target cells, a line of human embryonic amnion cells, were infected with $\mathrm{HSV} 1$, and ${ }^{\mathbf{5 1}} \mathrm{Cr}$ labelled as previously described (Russell et al., 1975). 104 infected and control target cells were incubated with 100 $\mu 1$ of CSF and $10^{6}$ peripheral blood mononuclear cells for 3 hours. at $37^{\circ} \mathrm{C}$. The remaining cell pellet and the supernatant were counted and the $\%{ }^{51} \mathrm{Cr}$ release calculated. The results are expressed both as specific ${ }^{51} \mathrm{Cr}$ release - as in the figure - and also as the separate percentages of ${ }^{51} \mathrm{Cr}$ released from infected and uninfected (control) cells. 


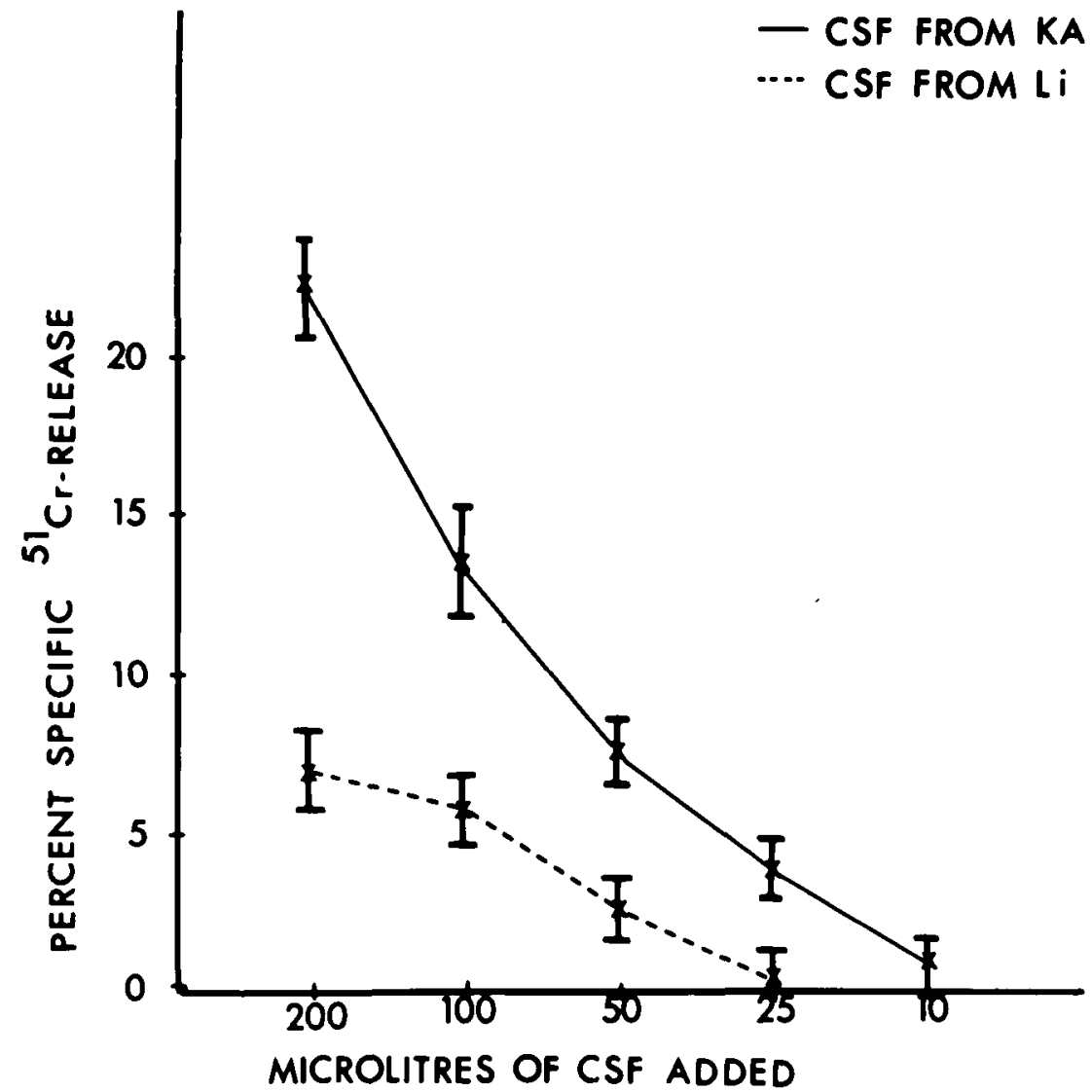

Figure $1-$ Percent Specific ${ }^{51} \mathrm{Cr}$ released from HSV1 infected target cells by lymphocytes in the presence of CSF from two subjects (KA and LI). The effect of serial dilutions of CSF is shown to demonstrate the amounts required in this assay system.

TABLE 1

Percent ${ }^{51} \mathrm{Cr}$ release from $\mathrm{HSVI}$ infected target cells by lymphocytes in the presence of CSF or serum. The ${ }^{51} \mathrm{Cr}$ released by CSF and serum from the same person is shown for seven subjects who have been selected to illustrate the various relationships found.

\begin{tabular}{|c|c|c|c|c|c|c|}
\hline \multirow{2}{*}{ Patient } & \multirow{2}{*}{ Age } & \multirow{2}{*}{ Specimen } & \multicolumn{2}{|c|}{$\begin{array}{l}\%^{51} \mathrm{Cr} \text { released by incubation with } \\
\mathrm{CSF} \text { and lymphocytes from: }\end{array}$} & \multirow{2}{*}{$\begin{array}{l}\text { Frequency of } \\
\text { previous } \\
\text { herpes infection }\end{array}$} & \multirow{2}{*}{$\begin{array}{c}\text { CSF } \\
\text { Protein } \\
\text { mg\% }\end{array}$} \\
\hline & & & $\begin{array}{c}\text { HSV1 } \\
\text { Infected cells* }\end{array}$ & Uninfected cells $\theta$ & & \\
\hline $\mathrm{Pe}$ & 47 & $\begin{array}{c}\text { Serum } \\
\text { CSF }\end{array}$ & $\begin{array}{r}26.8 \\
8.0\end{array}$ & $\begin{array}{l}4.4 \\
3.7\end{array}$ & Occasional & 65 \\
\hline Vo & 53 & $\begin{array}{l}\text { Serum } \\
\text { CSF }\end{array}$ & $\begin{array}{l}24.7 \\
18.2\end{array}$ & $\begin{array}{l}8.0 \\
7.0\end{array}$ & None & 76 \\
\hline $\mathrm{Ra}$ & 33 & $\begin{array}{c}\text { Serum } \\
\mathrm{CSF}\end{array}$ & $\begin{array}{l}24.5 \\
16.4 \\
\end{array}$ & $\begin{array}{l}5.4 \\
5.7 \\
\end{array}$ & Regular & 144 \\
\hline No & 40 & $\begin{array}{c}\text { Serum } \\
\text { CSF }\end{array}$ & $\begin{array}{l}38.4 \\
23.9 \\
\end{array}$ & $\begin{array}{l}5.0 \\
4.0 \\
\end{array}$ & Often & 75 \\
\hline $\mathrm{De}$ & 28 & $\begin{array}{c}\text { Serum } \\
\text { CSF }\end{array}$ & $\begin{array}{l}40.3 \\
15.9 \\
\end{array}$ & $\begin{array}{l}4.9 \\
4.6 \\
\end{array}$ & Often & 35 \\
\hline $\mathrm{Sa}$ & 40 & $\begin{array}{c}\text { Serum } \\
\text { CSF }\end{array}$ & $\begin{array}{r}15.3 \\
3.6 \\
\end{array}$ & $\begin{array}{l}3.8 \\
3.0 \\
\end{array}$ & None & 29 \\
\hline $\mathrm{Mc}$ & 44 & $\begin{array}{l}\text { Serum } \\
\text { CSF }\end{array}$ & $\begin{array}{l}4.5 \\
3.5\end{array}$ & $\begin{array}{l}3.8 \\
3.7\end{array}$ & None & 66 \\
\hline
\end{tabular}

*Background release from infected target cells alone $=2.8( \pm 0.7)$.

$\leftrightarrow$ Background release from uninfected target cells alone $=4.6( \pm 1.1)$.
Specific ${ }^{51} \mathrm{Cr}$ release $=\frac{\mathrm{I}-\mathrm{N}}{\mathrm{F}_{\mathrm{I}}} \times 100$

$I=c p m$ of supernatant after incubation of infected target cells with CSF and lymphocytes minus the background ${ }^{51} \mathrm{Cr}$ release.

$\mathrm{N}=\mathrm{cpm}$ released from uninfected cells minus background.

$\mathrm{F}_{\mathrm{I}}=\mathrm{cpm}$ after freeze thawing of infected targets $\mathrm{x} 5$.

$1.0 \mathrm{ml}$ of CSF was obtained during routine lumbar myelography and a serum sample was later obtained from the same patient. CSF was discarded if it contained 5 $\mathrm{RBC} / \mathrm{cu} . \mathrm{mm}$., in view of possible contamination with plasma under these circumstances. 40 paired serum and CSF specimens were obtained.

\section{RESULTS}

Initial experiments were performed with serial dilutions of CSF to determine the optimum concentration in this assay (Fig. 1). In subsequent experiments $100 \mu \mathrm{l}$ were used. 20 of the CSF specimens gave a significant ${ }^{51} \mathrm{Cr}$ release. In all cases the paired serum sample was also positive and had a higher \% release (see Table).

The $\%{ }^{51} \mathrm{Cr}$ release did not correlate with the total protein concentration of CSF, even when the seropositive patients alone were considered (see Table 1).

Three patients with persistent and frequent episodes of oral herpes had relatively high ${ }^{51} \mathrm{Cr}$ release from both CSF and from serum. No CSF specimen induced ${ }^{51} \mathrm{Cr}$ release when incubated with infected targets in the presence of fresh complement most serum specimens did (Russell et al., 1975).

\section{DISCUSSION}

It is clear that with sufficiently sensitive techniques anti-herpes antibody can be found in cerebrospinal fluids that would otherwise be considered normal, and it seems likely that it is this antibody that may be responsible for the maintenance of herpes virus latency in nerve ganglia (Stevens and Cook, 1974). The anti- 
body detected by our technique is known to be of IgG type (Shore et al., 1976) but whether any of it is produced locally cannot be clearly answered from our data. Nevertheless the normal range for the $\operatorname{IgG}$ concentration of CSF has been frequently assessed and is usually below $13 \%$ of the total CSF protein (Yahr et al., 1954; Lamoureux et al., 1975). Tourtelotte (1972) has suggested that the normal CSF: serum IgG ratio is approximately $1: 275$. Thus the ratio obtained by comparing the percentages of ${ }^{51} \mathrm{Cr}$ released by CSF and serum can be used to assess the possibility of local antibody synthesis by comparison with his suggested figure. It would seem that the ratio is very much lower than this in some patients, and this is at least consistent with the possibility of local stimulation and production of this antibody.

Antibody dependent cell mediated immunity (ADC) is an efficient mechanism for the lysis of herpes infected cells and it has been suggested that it might have a protective role in vivo (Rager-Zisman and Allison, 1976). The mononuclear cell mediating this phenomenon in our system is a "null cell" - that is: a cell that neither forms rosettes with sheep red blood cells (a T cell) nor has surface immunoglobulin markers (a B cell). As the few lymphocytes present in normal CSF are almost all T-cells, (Manconi et al., 1976), it seems unlikely that the ADC effect of CSF antibody has an in vivo role.

\section{REFERENCES}

CAPPEL. R., THIRY, L. and CLINET, G. (1975). Viral antibodies in the CSF after acute CNS infection. Archives of Neurology. 32, 629-631.

LAMOUREUX, F., JOLLICOEUR, R.. GIARD. N., ST-HILAIRE, $M$. and DUPLANTIS, F. (1975). Cerebrospinal fluid proteins in multiple sclerosis. Neurology. 25. 537-546.

LERNER, A. M.. LAUTER, C. B.. NOLAN, D. C. and SHIPPEY, M. J. (1972). Passive hemagglutinating antibodies in cerebrospinal fluids in herpes virus encephalitis. Proceedings of the Society for Experimental Biology and Medicine. 140. 1460- 1466.

MANCONI, P. E., ZACCHEO, D.. BUGIANI, O., SADDA, M. F.. GRIFONI. V. and MANTOVANI. G. (1976). T and B lymphocytes in normal cerebrospinal fluid. New England Journal of Medicine, 294, 49.

RAGER-ZISMAN. B. and ALLISON. A. C. (1976). Mechanism of immunologic resistance to herpes simplex virus 1 (HSV-I) infection. Journal of Immunology, 116. 35-40.

RUSSELL, A. S.. PERCY, J. S.. and KOVITHAVONGS, T. (1975). Cellmediated immunity to herpes simplex in humans: Lymphocyte cytotoxicity measured by ${ }^{5} \mathrm{Cr}$ release from infected cells. Infection and Immunity. 11. 355-359.

RUSSELL. A. S. and SAETRE. A (1976). Antibodies to herpes-simplex virus in "normal" cerebrospinal fluid. Lancet. 1. 64-65.

SHORE, S. L., BLACK. C. M. MALEWICZ. M. F., WOOD. P. A. and NAHMIAS, A. J. (1976). Antibody dependent cell mediated cytotoxicity to target cells infected with type 1 and type 2 herpes simplex virus. Journal of Immunology. 116. 194-201.

STEVENS. J. G. and COOK. M. L. (1974). Maintenance of latent herpetic infection: An apparent role for anti-viral $\lg G^{\prime}$. Journal of Immunology. 113. 1685-1693.

TOURTELOTTE. W. W. (1972). Interaction of local central nervous system immunity and systemic immunity in the spread of multiple sclerosis demyelination. In: F. Wolgram. G. W. Ellison. J. G. Stevens and J. M. Andrews (Eds.). Multiple Sclerosis. Ch. 16, New York, N. Y. Academic Press. pp. 285-332.

YAHR, M. D., GOLDENSOLM, S. S. and KABOT. E. A. (1954). Further studies on the gamma globulin content of cerebrospinal fluid in multiple sclerosis and other neurological diseases. Annals of the New York Academy of Sciences, 58, 613-627. 